\title{
遊離甲状腺ホルモン濃度とTSH濃度間に解離を認める 病態に関する検査方法と臨床について
}

昭和大学藤が丘病院内科内分泌代謝科 ${ }^{1)}$, 伊藤病院 ${ }^{2)}$

久岡 俊 彦 ${ }^{1)}$, 飯 野史 郎 ${ }^{1)}$, 斎 藤 一二三 ${ }^{2)}$, 吉 村 弘 $^{2)}$,
石 川 直 文 ${ }^{2)}$, 百 渓 尚 子 ${ }^{2)}$, 伊 藤 國 彦 ${ }^{2}$

\author{
Studies on Patients with a Discrepancy between Free Thyroid \\ Hormones and Thyrotropin Values
}

\section{Toshihiko HISAOKA, Shiro IINO, Hifumi SAITOH*, Hiroshi YOSHIMURA*, Naofumi ISHIKAWA*, Naoko MOMOTANI* and Kunihiko ITO*}

\author{
Division of Endocrinology and Metabolism, Department of Internal Medicine, \\ Showa University Fujigaoka Hospital, Yokohama and *Ito Hospital, Tokyo, Japan
}

Thyroid function has been almost exactly evaluated by the measurement of serum free thyroxine (FT4), free triiodothyronine (FT3) and thyrotropin (TSH) concentrations. However, we occasionally experience patients who show a discrepancy between free thyroid hormones and TSH values, and the assessment of thyroid function in such cases is extremely difficult. Thyroid hormone autoantibodies (THAA) interfere with radioimmunoassay (RIA) of FT4 and FT3 by giving inappropriate values. To investigate the incidence of THAA, immune precipitation of patients' sera after incubation with labelled T4 $\left({ }^{125} \mathrm{I}-\mathrm{T} 4\right)$ or T3 $\left({ }^{125} \mathrm{I}-\mathrm{T} 3\right)$ analog tracer was done in 394 patients with thyroid diseases. 9 patients $(2.3 \%)$ showed an increased binding of ${ }^{125} \mathrm{I}-\mathrm{T} 4$ or ${ }^{125} \mathrm{I}-\mathrm{T} 3$ analog. Heterophilic antimouse antibodies in a patient's serum (human antimouse immunoglobulin antibodies: HAMA) can interfere in two-site immunometric assays (IMA) using mouse monoclonal antibodies and result in spuriously increased serum TSH concentrations. Manufacturers now customarily add nonspecific mouse immunoglobulins into their assay kits to absorb HAMA and prevent such interference. This approach may not always be enough to prevent HAMA interference in all samples. In 14 thyrotoxic patients with inappropriately high TSH measured by an IMA kit, we measured the levels of TSH by the further addition of mouse serum into this kit. Their serum TSH levels were fully suppressed except for 2 patients with a syndrome of inappropriate secretion of TSH (SITSH). The presence of abnormal albumin in the serum also interferes with RIA of FT4 and FT3. We experienced a female case of Graves' disease treated with methimazole who showed an inappropriately high serum FT3 measured by an analog tracer RIA kit, whose serum FT4, FT3 and TSH were $1.31 \mathrm{ng} / \mathrm{dl}, 19.3 \mathrm{pg} / \mathrm{ml}$ and $1.9 \mu \mathrm{U} / \mathrm{ml}$ respectively. Although the anti-T3 autoantibody was considered to be present initially, immune precipitation of her serum with ${ }^{125} \mathrm{I}-\mathrm{T} 3$ analog tracer gave a negative result. In order to elucidate this finding, Sephadex-G200 chromatography of her serum after incubation with ${ }^{125} \mathrm{I}-\mathrm{T} 3$ analog tracer was done. Radioactivity of her serum in albumin fraction was significantly higher than that of normal control serum to indicate the presence of abnormal albumin in the serum.

In conclusion, to assess the thyroid function of a patient with a discrepancy between free thyroid hormones and TSH values, it is important to consider the presence of THAA, HAMA, or rarely, an abnormal albumin.

$$
\text { 第70巻 第6号 }
$$


Keywords: THAA, HIAMA, abnormal albumin, discrepancy, interference

\section{はじめに}

遊離甲状腺ホルモン $\left(\mathrm{FT}_{4}\right.$ および $\left.\mathrm{FT}_{3}\right)$ が一般に測定されるようになり，また，甲状腺刺激ホルモン(TSH) の測定法が高感度アッセイになった今日， $\mathrm{FT}_{4}, \mathrm{FT}_{3}, \mathrm{TSH}$ の 項目を測定することにより甲状腺機能をほぼ 正確に評価できるようになった。しかし，時折，遊離甲状腺ホルモンと TSHの各測定值間に解離を認める 症例に遭遇し，その検査值の評価に苦しむ場合がある。

latent hyperthyroidism，latent hypothyroidism，TSH分泌のtime lagについては，臨床経過から解離の原因 を知ることができる。しかし，測定系に影響を与える物質が存在して，測定值が見掛上異常值を示すため に生じる解離は，その原因を臨床経過から判断するのは困難である。測定系に影響を与える物質としては, 抗甲状腺ホルモン抗体 (thyroid hormone autoantibodies:THAA ${ }^{1)}$ ) や家族性異常アルブミン血性高 $\mathrm{T}_{4}$ 血症 (familial dysalbuminemic hyperthyroxinemia:FDH) に代表される異常アルブミンの存在があるが, これらの 物質はFT あるいはFT ${ }_{3}$ の測定值に見掛上の異常值を生じさせる ${ }^{233}$ 。また，高感度 $\mathrm{TSH}$ 測定キットに用いら れているマウスモノクローナル抗体に反応する抗マウス IgG抗体 (human antimouse immunoglobulin antibodies:HAMA ${ }^{4}$ ） が血中に存在する場合には，TSHの測定值は見掛上高值となる5)。解離の原因として，こ れらが除外された後にTSH 産生腫瘍, 甲状腺ホルモン不応症などのいわゆるTSH 分泌過唾症(SITSH)につ いての検索を行うことになる。こうすることによって, 遊離甲状腺ホルモン值とTSH值との間に解離を示 す症例に対する合理的なアプローチができると考えられる。

我々は，遊離甲状腺ホルモン值とTSH值の間に解離を認める症例に対するアプローチとして，THAA， HAMA，異常アルブミンの検出法について検討するとともに，各種甲状腺疾患におけるTHAAの出現頻度 についても検討を行ったので報告する。

\section{対象および方法}

$\mathrm{FT}_{4}$ およびFT ${ }_{3}$ はアナログ法を用いた市販のRIAキット（アマレックス $\mathrm{M} \mathrm{FT}_{4}$ およびFT $\mathrm{FT}_{3} ;$ アマシャム社） で測定し，TSHはtwo-site immunometric assayによる高感度測定法（デルフィアTSH；ファルマシア社）で 測定した。抗サイログロブリン抗体(TGHA)拉よび抗甲状腺マイクロゾーム抗体(MCHA)は受身凝集反応 （富士レビオ）で，TSH receptor antibody(TRAb)はradioreceptor assay（バクスター社）でそれぞれ測定し た。正常值は, $\mathrm{FT}_{4}$ 0.8-1.9ng/dl, $\mathrm{FT}_{3} 2.5-5.5 \mathrm{pg} / \mathrm{ml}$, TSH 0.3-3.5 $\mu \mathrm{U} / \mathrm{ml}, \mathrm{TGHA}(-), \mathrm{MCHA}<100 \times$, TRAb-10-10\%である。

1) THAAについて

\section{a) THAAの検出法}

THAAの存在は，患者血清とアマレックス M-FT またはFT のキットに使用されている analog tracer（ ${ }^{125} \mathrm{I}-$ polyaminocarboxy $\mathrm{T}_{4}$ または $\mathrm{T}_{3}$ ；アマシャム社）との結合率で検討した。

患者血清 $50 \mu 1$ にanalog tracer $100 \mu 1$ を加えて混和し， $37^{\circ} \mathrm{C} て ゙ 60$ 分間インキュベートした後，アッセイ 緩衝液（10mM Tris-HCl, $50 \mathrm{mM} \mathrm{NaCl}, \mathrm{pH} 7.5 ） を 350 \mu 1$ 加え，総量を $500 \mu 1$ とする。そこへ，30\% polyethylene glycol(PEG)溶液（10mM Tris- $\mathrm{HCl}, 1 \mathrm{M} \mathrm{NaCl}, \mathrm{pH} 7.5)$ を $500 \mu 1$ 加え，遠沈 (3000rpm, $4{ }^{\circ} \mathrm{C}$, 15min.）した後，沈渣の放射活性を測定し，加えたanalog tracerの総放射活性に対する割合（bound/total\%) を結合率とした。この ${ }^{125} \mathrm{I}-\mathrm{T}_{4}$ analog tracerまたは ${ }^{125} \mathrm{I}-\mathrm{T}_{3}$ analog tracer との結合率を我々はABR4またはABR3 として表現した。 
ABR4 (\%) : ${ }^{125} \mathrm{I}-\mathrm{T}_{4}$ analog tracer binding ratio

ABR3 (\%) : ${ }^{125} \mathrm{I}_{-} \mathrm{T}_{3}$ analog tracer binding ratio

\section{b) THAAの発現頻度}

1991 年 11 月の 1 ケ間に伊藤病院を受診した初診甲状腺疾患患者394例全例において ABR4およびABR3 を測定することにより，THAAのスクリーニングを行った。その内訳は，バセドウ病129例（未治療47例）, 橋本病63例 (未治療 47 例), 結節性甲状腺腫 118 例, 単純性甲状腺腫 73例, 亜急性甲状腺炎 11 例であっ た。また，正常対照として正常者29例の血清について同様の検討を行い, 正常者結合率のmean+4SD以上 を有意な結合率とした。

\section{2) HAMAについて}

\section{a) HAMAの検出法}

2種のマウスモノクローナル抗体を用いるimmunometric assay(IMA)法でTSHを測定する場合，2種の抗 体すなわち固相抗体と標識抗体がHAMAによってリンクされ，測定值が見掛上高值となる症例がある。そ こで, マウス全血清（Cappel社）を測定系に添加し，HAMAの影響を取り除く以下の検討を行った。

マウス全血清を測定系で用いる緩衝液 $2 \mathrm{ml}$ で溶解する。マウス全血清溶解液と患者血清を等量混合し, 患者血清中に存在するHAMAを吸収する。この等量混合液から測定したTSH濃度を2倍し, 患者原血清中 のTSH濃度と比較する。前者が後者より有意に低下した場合HAMA陽性と判定した。

\section{b) HAMAの臨床的検討}

$\mathrm{FT}_{4}$ またはFT 值が高值であるにもかかわらずTSH值が十分抑制されておらず解離を示したバセドウ病 12 例, TSH産生下垂体腫瘍, 甲状腺ホルモン不応症（全身型）各1例の計14例の血清について, マウス全血 清添加前後におけるTSH值の変化を検討した。マウス全血清添加後にTSH值が十分抑制されればHAMA陽 性と判定した。

3) 異常アルブミンについて

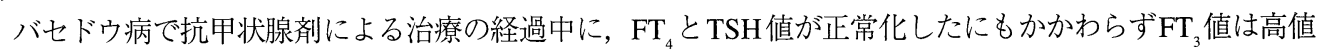
が持続し，解離を示した27歳女性例の血清について検討した。この症例では前記の方法による THAAの検 索結果は陰性であった。

患者血清 $500 \mu 1$ と ${ }^{125} \mathrm{I}-\mathrm{T}_{3}$ analog tracer $500 \mu \mathrm{l}$ を混合し, $37^{\circ} \mathrm{C} て ゙ 2$ 時間インキュベートした後, 室温に戻 して, Sephadex-G200のカラムにてゲル濾過を行った。

上記と同様の方法で, 正常血清および抗 $\mathrm{T}_{3}$ 抗体保有血清をゲル濾過し, ${ }^{125} \mathrm{I}_{-} \mathrm{T}_{3}$ analog tracer 単独のものも ゲル濾過した。

分光光度計にて分画の蛋白定量を行うとともに, 分画の放射活性を測定した。また, アルブミン分画は アルブミン発色試液を用いたBCG 法（A/GB-テストワコー；和光純薬）で確認した。

結果

\section{1) THAAの発現頻度}

甲状腺疾患患者 394例と正常対照 29例におけるABR4 およびABR3 の測定結果はFig.1およびFig.2に示す

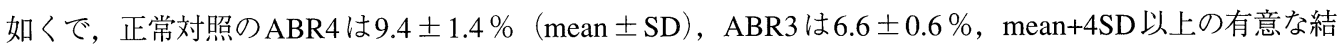
合率はABR4 $\geqq 15 \%, A B R 3 \geqq 9 \%$ となた。

ABR4が陽性を示した例は，バセドウ病 129 例中 5例（内未治療 1 例)，橋本病63例中 1 例で合計6例に認 められ，ABR3 が陽性を示した例は，バセドウ病 129 例中 1 例，橋本病63例中 2 例で合計 3 例に認められた。 

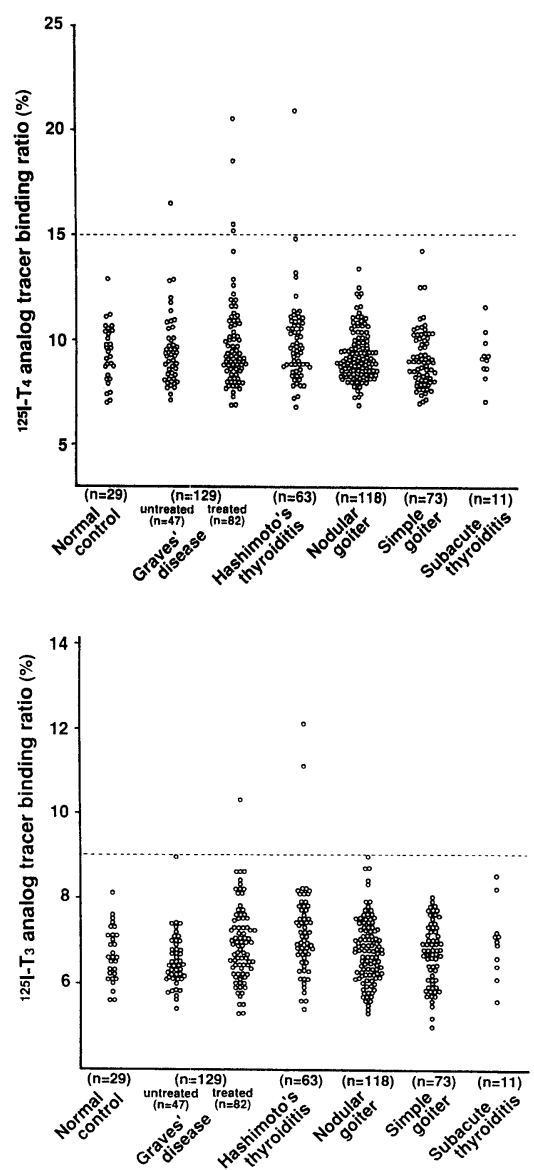

Fig. 1 Binding of ${ }^{125} \mathrm{I}_{-} \mathrm{T}_{4}$ analog tracer to sera in 394 patients with thyroid disease. (mean $+4 \mathrm{SD}$ in 29 normal controls: $15 \%$ )

Fig. 2 Binding of ${ }^{125} \mathrm{I}-\mathrm{T}_{3}$ analog tracer to sera in 394 patients with thyroid disease. (mean $+4 \mathrm{SD}$ in 29 normal controls: $9 \%$ )

これら9例の陽性例中，バセドウ病は 1 例を除いていずれも抗甲状腺薬による既往治療があり，橋本病はい ずれも未治療の症例であった。その他の甲状腺疾患においては, ABR4, ABR3ともに陽性例は認められな かった。以上の結果から, THAAの頻度は甲状腺疾患全体で394例中 9 例 $(2.3 \%)$, バセドウ病と橋本病の いわゆる自己免疫性甲状腺疾患では192例中 9 例 $(4.7 \%)$ であった。疾患別にみると，バセドウ病では129 例中 6例 $(4.7 \%)$, 橋本病では63例中3例 $(4.8 \%)$ であった。

Table1にABR4 陽性例6例とABR3 陽性例3例の検査デー夕を示す。ABR4またはABR3が陽性の場合ア ナログ法で測定した甲状腺ホルモン值は見掛上の高值を示すが，今回スクリーニングを行って陽性と判定さ れたとは言っても，FT $\mathrm{FT}_{4}$ たはFT 值と TSH值との間に明らかな解離があると認識できるほどの症例はなか った。TGHA との関係は，THAA陽性例 9 例中TGHA 陰性例は 5 例，陽性例は4例であった。

2) HAMAの検討成績 (Fig.3, Table2)

バセドウ病の例では，1例を除いていずれもマウス全血清添加後にTSH 值は $0.05 \mu \mathrm{U} / \mathrm{ml}$ 未満に抑制され， 残る 1 例もマウス全血清添加前後でTSH $1.0 \mu \mathrm{U} / \mathrm{ml}$ から $0.08 \mu \mathrm{U} / \mathrm{ml}$ まで十分抑制された。この結果から, $\mathrm{FT}_{4}$ またはFT 3 值が高值であるにもかかわらず，TSH值が十分抑制されずに解離を示した原因はHAMA であ ると判定された。解離の原因としてTHAAを除外するために, ABR4とABR3も一部の例で測定したが, Case 9 を除いていずれも陰性であった。Case 9は, FT ${ }_{3} 6.6 \mathrm{pg} / \mathrm{ml}$ に比較して, $\mathrm{FT}_{4} 5.94 \mathrm{ng} / \mathrm{dl}$ と高值であり, 
Table 1 Data on 6 patients with an increased binding of ${ }^{125} \mathrm{I}_{-} \mathrm{T}_{4}$ analog (upper table) and 3 patients with an increased binding of ${ }^{125} \mathrm{I}-\mathrm{T}_{3}$ analog (lower table). $\mathrm{FT}_{4}$ and $\mathrm{FT}_{3}$ were measured by analog tracer RIA kit.

\begin{tabular}{cccccccc}
\hline $\begin{array}{l}\text { Case } \\
\text { No. }\end{array}$ & $\begin{array}{c}\text { diag- } \\
\text { nosis }\end{array}$ & $\begin{array}{c}\text { ABR 4 } \\
(\%)\end{array}$ & $\begin{array}{c}\mathrm{FT} 4 \\
(\mathrm{ng} / \mathrm{dl})\end{array}$ & $\begin{array}{c}\mathrm{FT} 3 \\
(\mathrm{pg} / \mathrm{ml})\end{array}$ & $\begin{array}{c}\text { TSH } \\
(\mu \mathrm{U} / \mathrm{ml})\end{array}$ & $\begin{array}{c}\text { TGHA } \\
\times\end{array}$ & Therapy \\
\hline 1 & HD & 20.9 & 0.60 & 1.7 & 145.2 & $(-)$ & no \\
2 & GD & 20.5 & 1.32 & 3.2 & 6.9 & 400000 & MMI \\
3 & GD & 18.5 & 1.53 & 5.9 & $<0.05$ & $(-)$ & PTU \\
4 & GD & 16.5 & 2.78 & 8.8 & $<0.05$ & 6400 & no \\
5 & GD & 15.5 & 1.02 & 6.2 & $<0.05$ & $(-)$ & MMI \\
6 & GD & 15.2 & 1.55 & 5.7 & 4.8 & $(-)$ & MMI \\
\hline $\begin{array}{l}\text { Normal } \\
\text { range }\end{array}$ & $<15$ & $0.8 \sim 1.9$ & $2.5 ~ 5.5$ & $0.3 \sim 3.5$ & $(-)$ & \\
\hline
\end{tabular}

\begin{tabular}{cccccccc}
\hline $\begin{array}{c}\text { Case } \\
\text { No. }\end{array}$ & $\begin{array}{c}\text { diag- } \\
\text { nosis }\end{array}$ & $\begin{array}{c}\mathrm{ABR} 3 \\
(\%)\end{array}$ & $\begin{array}{c}\mathrm{FT} 4 \\
(\mathrm{ng} / \mathrm{dl})\end{array}$ & $\begin{array}{c}\mathrm{FT} 3 \\
(\mathrm{pg} / \mathrm{ml})\end{array}$ & $\begin{array}{c}\text { TSH } \\
(\mu \mathrm{U} / \mathrm{ml})\end{array}$ & $\begin{array}{c}\text { TGHA } \\
\times\end{array}$ & Therapy \\
\hline 1 & $\mathrm{HD}$ & 12.1 & 0.30 & 2.2 & 88.0 & $(-)$ & no \\
2 & $\mathrm{HD}$ & 11.1 & 1.60 & 4.4 & 1.4 & 100000 & no \\
3 & $\mathrm{GD}$ & 10.3 & 0.61 & 5.0 & 0.07 & 100 & $\mathrm{MMI}$ \\
\hline $\begin{array}{c}\text { Normal } \\
\text { range }\end{array}$ & $<9$ & $0.8 \sim 1.9$ & $2.5 \sim 5.5$ & $0.3 \sim 3.5$ & $(-)$ & \\
\hline
\end{tabular}

ABR 4: ${ }^{125}\left[-T_{4}\right.$ analog tracer binding ratio

ABR 3: ${ }^{125} \mathrm{~T}_{-} \mathrm{T} 3$ analog tracer binding ratio

HD: Hashimoto's disease, GD: Graves' disease

MMI: methimazole, PTU: propylthiouracil

$\mathrm{FT}_{4}$ 值と $\mathrm{FT}_{3}$ 值の間にも解離が認められ，HAMA と抗 $\mathrm{T}_{4}$ 抗体（ABR4:57.0\%）を同時に保有していた症例で あった。

Case 13 と Case 14 は，それぞれマウス全血清添加前後でTSH 值が3.0 $\mu \mathrm{U} / \mathrm{ml}$ から $3.1 \mu \mathrm{U} / \mathrm{ml}, \quad 1.6 \mu \mathrm{U} / \mathrm{ml}$ から $1.5 \mu \mathrm{U} / \mathrm{ml}$ と有意な変化はみられなかった。また，ABR4はそれぞれ $10.2 \%, 7.0 \%, \mathrm{ABR} 3$ は $6.9 \%$, $5.4 \%$ といずれも陰性であり, HAMA とともにTHAAも除外された。その後検索をすすめ, Case 13 はTSH 産生下垂体腫瘍, Case 14は甲状腺ホルモン不応症（全身型）と診断された。Case 13は, 下垂体腫瘍を Hardyの手術で摘徐し, 甲状腺機能は正常化したが, 興味あることに, その 1 年後にTRAb $62.4 \%$ と陽性化 し, びまん性甲状腺腫を伴って $\mathrm{FT}_{4} 7.81 \mathrm{ng} / \mathrm{dl}, \mathrm{FT}_{3}>15.0 \mathrm{pg} / \mathrm{ml}, \mathrm{TSH}<0.05 \mu \mathrm{U} / \mathrm{ml}$ とバセドウ病を発症した。

\section{3）異常アルブミンの検出結果}

検討したバセドウ病患者血清のデータは，メチマゾール $15 \mathrm{mg} / \mathrm{day}$ 服用時 $\mathrm{FT}_{4} 1.31 \mathrm{ng} / \mathrm{dl}, \mathrm{FT}_{3} 19.3 \mathrm{pg} / \mathrm{ml}, \mathrm{TSH}$ $1.9 \mu \mathrm{U} / \mathrm{ml}$ と FT 值に解離が認められたが, ABR3は6.5\%と陰性であった。また, TRAbは $24.0 \%$ \%った。

Fig.4 に正常血清, 患者血清, 抗 $\mathrm{T}_{3}$ 抗体保有血清および225 $\mathrm{I}_{3}$ analog tracerの各チャートにおける蛋白分画 (実線)とそれに占める放射活性（点線部）の分布を示した。BCG法で確認したアルブミン分画は, Fraction number 38付近すなわち第3ピークにあった。なお, ${ }^{125} \mathrm{I}-\mathrm{T}_{3}$ analog tracerチャートのFraction number 38付近にあるピークはアルブミンであり， analog tracer製造時に添加されたBSA（Bovine serum albumin） が検出されたものである。

正常血清と患者血清の各チャートで, アルブミンピークに占める放射活性の割合を計算した結果, 正常 血清で $28 \%$, 患者血清で $41 \%$ \%あった。 ${ }^{125} \mathrm{I}-\mathrm{T}_{3}$ analog は, 本来アルブミンとある程度は結合するため6), 正 常血清でも結合が認められたが, それ以上に患者血清に扔いて有意に高い結合率を示した。抗 $\mathrm{T}_{3}$ 抗体保有 血清のチャートでは，放射活性の殆どが第2ピークに集まっており，従ってこれがグロブリン分画であると 


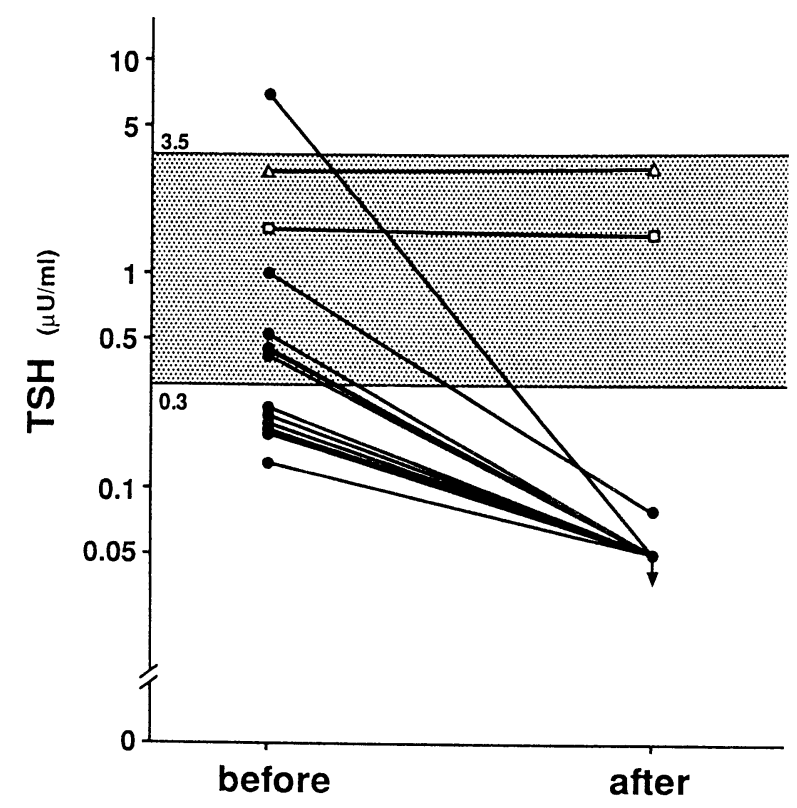

\section{Further Addition of Mouse Serum}

Fig. 3 Changes in serum TSH levels measured before and after the further addition of mouse serum into immunometric assay kit in 14 thyrotoxic patients with inappropriately high TSH measured by this kit. Closed circles are Graves' disease ( $)$, open triangle is TSHsecreting pituitary tumor $(\triangle)$ and open square is generalized resistance to thyroid hormone $(\square)$. Shaded area is normal range.

考えられた。患者血清のチャートで第 2 ピークに放射活性が検出されていないことは，THAA検索陰性の結 果と一致するものである。

以上の結果から, 患者血清中のアルブミンは ${ }^{125} \mathrm{I}-\mathrm{T}_{3}$ analog と高い結合率を示し，このことが $\mathrm{FT}_{3}$ 值の解離 した原因であったと考えられた。このことを別な方法で確認するために，正常血清と患者血清をそれぞれア マレックス M-FT のキットでアッセイした上清のゲル滤過を試みた。その結果，アルブミンピークに占める 放射活性の割合は，正常血清で5\%，患者血清で $21 \%$ \%あり顕著な差異が認められた。

考察

遊離甲状腺ホルモン值とTSH值の間に解離を認める症例に遭遇した場合, 様々な可能性を考えなくては ならないが，なかでも測定系に影響を与える物質が原因している可能性を考慮することで合理的なアプロー チができる。

THAAの存在は，これを検出するために行われるスクリーニング検査以外では，甲状腺ホルモン值が臨床 所見やTSH值と解離を示すことから，その存在が推定され，さらに検索をすすめて見出される場合がほと んどである。

我々の行ったTHAAスクリーニングの結果は, THAAの発現頻度をまとめた報告2)からみれば多い方では 
Table 2 Data on 14 patients in Fig. 3.

\begin{tabular}{|c|c|c|c|c|c|c|c|c|}
\hline $\begin{array}{l}\text { Case } \\
\text { No. }\end{array}$ & $\begin{array}{l}\text { diag- } \\
\text { nosis }\end{array}$ & $\begin{array}{c}\mathrm{FT}_{4} \\
\text { (ng/dl) }\end{array}$ & $\begin{array}{c}\mathrm{FT}_{3} \\
(\mathrm{pg} / \mathrm{ml})\end{array}$ & $\begin{array}{c}\text { TSH } \\
(\mu \mathrm{U} / \mathrm{ml})\end{array}$ & $\begin{array}{c}\text { TSH }^{*} \\
(\mu \mathrm{U} / \mathrm{ml})\end{array}$ & $\begin{array}{c}\text { TRAb } \\
(\%)\end{array}$ & $\begin{array}{c}\text { ABR4 } \\
(\%)\end{array}$ & $\begin{array}{c}\mathrm{ABR} 3 \\
(\%)\end{array}$ \\
\hline 1 & GD & 2.12 & 5.6 & 0.20 & $<0.05$ & 27.4 & 9.6 & 6.7 \\
\hline 2 & GD & 2.10 & 6.8 & 0.13 & $<0.05$ & 17.8 & 8.5 & 6.7 \\
\hline 3 & GD & 3.78 & 11.1 & 0.18 & $<0.05$ & 40.9 & - & - \\
\hline 4 & GD & 2.06 & 7.6 & 0.52 & $<0.05$ & 60.6 & 9.0 & 8.3 \\
\hline 5 & GD & $>10.0$ & 22.8 & 0.45 & $<0.05$ & 45.4 & - & - \\
\hline 6 & GD & 4.33 & 11.1 & 0.22 & $<0.05$ & 5.5 & 6.0 & 5.7 \\
\hline 7 & GD & 2.38 & 7.2 & 0.41 & $<0.05$ & 72.9 & 10.2 & 7.6 \\
\hline 8 & GD & 3.83 & 8.6 & 0.44 & $<0.05$ & 22.7 & - & - \\
\hline 9 & GD & 5.94 & 6.6 & 0.24 & $<0.05$ & 77.1 & 57.0 & 7.5 \\
\hline 10 & GD & 4.43 & 14.0 & 1.0 & 0.08 & 46.6 & - & - \\
\hline 11 & GD & 1.30 & 8.6 & 0.19 & $<0.05$ & 39.7 & - & - \\
\hline 12 & GD & 2.45 & 7.7 & 6.9 & $<0.05$ & 59.8 & 6.7 & 5.2 \\
\hline 13 & $\Delta$ & 2.76 & 6.6 & 3.0 & 3.1 & 8.2 & 10.2 & 6.9 \\
\hline 14 & $\square$ & 2.94 & 6.2 & 1.6 & 1.5 & 1.4 & 7.0 & 5.4 \\
\hline \multicolumn{2}{|c|}{$\begin{array}{c}\text { Normal } \\
\text { range }\end{array}$} & $0.8 \sim 1.9$ & $2.5 \sim 5.5$ & $0.3 \sim 3.5$ & $0.3 \sim 3.5$ & $-10 \sim 10$ & $<15$ & $<9$ \\
\hline \multicolumn{9}{|c|}{$\begin{array}{l}\text { ABR 4: }{ }^{122}-\mathrm{T}_{4} \text { analog tracer binding ratio } \\
\text { ABR 3: } 125 \mathrm{I}-\mathrm{T} \text { analog tracer binding ratio } \\
\text { GD: Graves' disease }\end{array}$} \\
\hline
\end{tabular}

Normal control serum $+{ }^{125} \mathrm{I}-\mathrm{T}_{3}$ analog tracer Patient's serum $+{ }^{125} \mathrm{I}-\mathrm{T}_{3}$ analog tracer
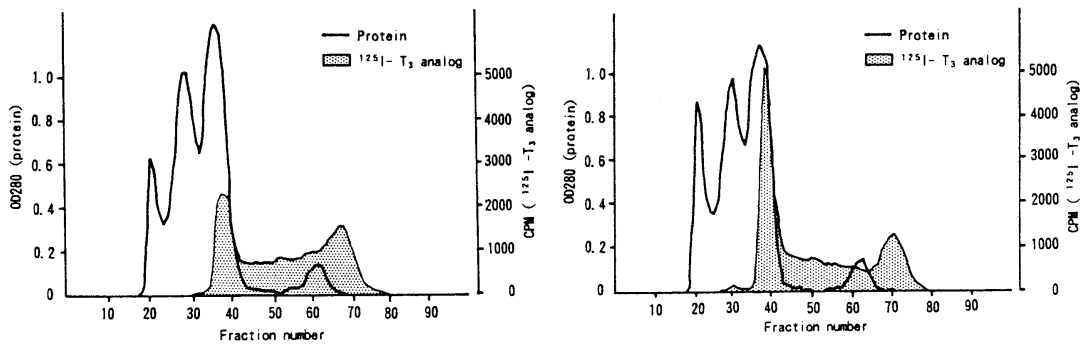

${ }^{125} \mathrm{I}-\mathrm{T}_{3}$ analog tracer

Anti- $\mathrm{T}_{3}$ autoantibody positive serum + ${ }_{125} \mathrm{I}_{-} \mathrm{T}_{3}$ analog tracer
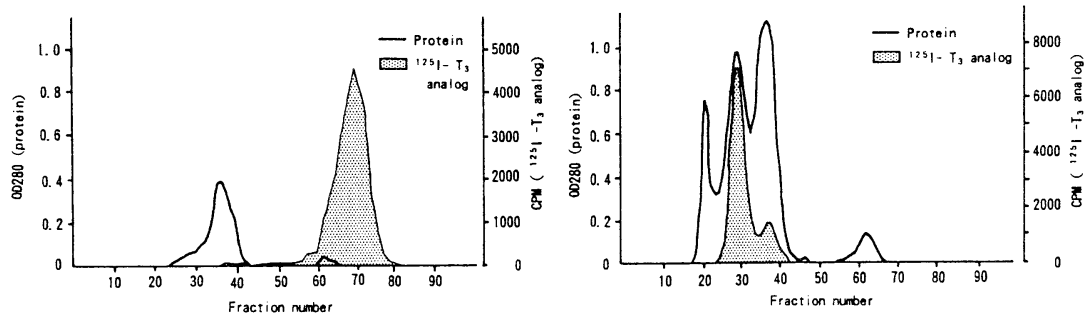

Fig. 4 Sephadex-G200 chromatography of normal control serum, patient's serum and anti-T3 autoantibody positive serum after incubation with ${ }^{125} \mathrm{I}_{-} \mathrm{T}_{3}$ analog tracer, and Sephadex-G200 chromatography of ${ }^{125} \mathrm{I}_{-} \mathrm{T}_{3}$ analog tracer only. 
なかった。また，従来の報告1778999 にみられるように，バセドウ病では免疫系に影響を及ぼすと言われている 抗甲状腺薬による既往治療例に陽性例が多く，橋本病では外因性甲状腺ホルモン剤の影響がない未治療例 に陽性例が多くみられた。

今回スクリーニングを行ってTHAA陽性と判定された症例の中には， $\mathrm{FT}_{4}$ またはFT ${ }_{3}$ 值と TSH值との間に 明らかな解離があると認識できるほどの症例はなかった。このことは, THAA 陽性と判定されたとはいって も，甲状腺ホルモン值と TSH値との間に明らかな解離を生じさせるようなTHAA 陽性例は，甲状腺疾患の 中にあってもきわめて稀である ${ }^{10)}$ 言われていることと一致する。それでは, 実際にFT 值との間に明らかな解離を生じさせるようなTHAAの頻度はどれ位かを検討してみた。1991年の 1 年間に 伊藤病院で, $\mathrm{FT}_{4}$ またはFT 值が臨床所見やTSH值と解離を示すことから THAAの存在が疑われ検索が行わ れた結果，陽性と判定された症例は，抗 $\mathrm{T}_{4}$ 抗体 40 例 (ABR4:37.5 $\pm 16.1 \%, 15.7 \sim 68.2 \%$ ), 抗 $\mathrm{T}_{3}$ 抗体39 例（ABR3:36.2 $\pm 23.4 \%, 9.9 \sim 94.3 \%$ ）であり，抗 $\mathrm{T}_{4}$ または $\mathrm{T}_{3}$ 抗体陽性は61例であった。これを 1991 年 の 1 年間に来院した外来患者の頭数 41,587 人で除すと $0.15 \%$ という頻度になり, 甲状腺疾患専門外来受診 者の 600 人に 1 人はこのようなTHAAをもっていると考えられた。

1985 年頃から，マウスモノクローナル抗体を用いるIMA 法の測定系に干渉を及ほし，TSHの測定值に見

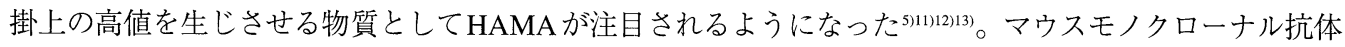
が, 主として癌患者の検查や治療の目的で静脈内投与された場合, 約半数の患者の血清中にHAMAが出現 する ${ }^{14)}$ 。特にこのような患者の血清でTSHを測定した場合，高頻度にHAMAが干渉してくる

HAMAは，ほとんどが異好抗体（Heterophilic antibody）であり，このHAMAの干渉を阻止する目的で マウスの $\gamma$ ーグロブリンが市販の測定キットに添加されているが，それでも阻止しきれなくて ${ }^{11115117)}$, TSHの 測定值が見掛上高值となってしまう症例がある。こういう症例が発見される糸口は, 甲状腺ホルモン值が高 值で甲状腺中毒症の症状を呈しているにもかかわらず，TSH值が十分抑制されないで解離を示す時であり， 特に未治療のバセドウ病患者で発見されやすい。こういう場合には，まずHAMAの干渉を疑い，マウス全 血清を測定系に添加してTSH值の変化を検討する。この検討を行っても TSH值に変化がなかった場合は, SITSHの可能性を考えなくてはならない。ただし, 今回のHAMAの検討成績からは, TSH值が正常值以下 に抑制されてはいるものの，な抒抑制不十分の症例は全例HAMA陽性であった。

HAMA 陽性例は未治療のバセドウ病患者で発見されやすいことから，1989年の 1 年間に伊藤病院を受診し た未治療バセドウ病患者812例を対象に，初診時のTSH值が十分抑制されていなかった症例を選び，これが 全例HAMAの干渉と仮定して，臨床上におけるHAMAの陽性頻度を推定した。このような症例は 812 例中 15 例認められ，頻度は約 $1.8 \%$ と推定された。この 15 例の初診時のTSH值は $0.34 \pm 0.21 \mu \mathrm{U} / \mathrm{ml}$ であった。

異常アルブミンを発見する糸口は，THAAの時と同様，甲状腺ホルモン值が臨床所見やTSH值と解離を 示すことからであるが, 本症はきわめて稀な疾患である。今回の異常アルブミンの症例も, 当初は抗 $\mathrm{T}_{3}$ 抗 体を疑い, ABR3 を測定したが $6.5 \%$ と陰性であり，検索をすすめた結果 ${ }^{125} \mathrm{I}-\mathrm{T}_{3}$ analogに高い結合性を示す 異常アルブミンであることが示唆された。なお，この異常アルブミンによってFT ${ }_{4}$ の測定值が干渉を受けな かったのは，アマレックス M-FT 9 のキットに添加されているアルブミンブロッカーが一因と考えられる。

この症例は過去に2児を出産しているが, 興味あることに, 出産時の臍带血で第 1 子, 第 2 子それぞれ $\mathrm{FT}_{4}$ 0.84, $0.97(\mathrm{~N}: 0.8-1.6 \mathrm{ng} / \mathrm{dl}), \mathrm{FT}_{3} 4.3,5.7(\mathrm{~N}: 0.3-1.1 \mathrm{pg} / \mathrm{ml}), \mathrm{TSH} 9.0,19.4(\mathrm{~N}: 1.8-21.1 \mu \mathrm{U} / \mathrm{ml})$ と母親同 様FT 值と TSH 值の間に解離を示した。このため家族性の異常アルブミン血症を疑い，3歳と2歳になる子 供の甲状腺機能検査を行ったところ，それぞれ $\mathrm{FT}_{4} 1.50,1.41(\mathrm{~N}: 0.6-2.2 \mathrm{ng} / \mathrm{dl}), \mathrm{FT}_{3} 5.5,5.3$ (N:3.6$6.4 \mathrm{pg} / \mathrm{ml}$ )，TSH 3.0, $0.86(\mathrm{~N}: 0.3-3.5 \mu \mathrm{U} / \mathrm{ml}$ ） と臍帯血で認められたような解離は消失していた。Gitlin ら 
${ }^{18}$ は， ${ }^{131} I$ でラベルした種々の濃度のヒトアルブミンを妊娠マウスに静脈内投与して，母体血清中の濃度に相 関した量のアルブミンが胎児組織に検出されたと報告している。このことから，本症例の異常アルブミンは 胎盤を通過した可能性が示唆され，この異常アルブミンの干渉によって臍帯血のFT 值が解離を示したと考 えられる。

$\mathrm{FT}_{4}$ またはFT 3 値と TSH 值の間に解離を認めた場合のアプローチの手順を Fig.5に示した。

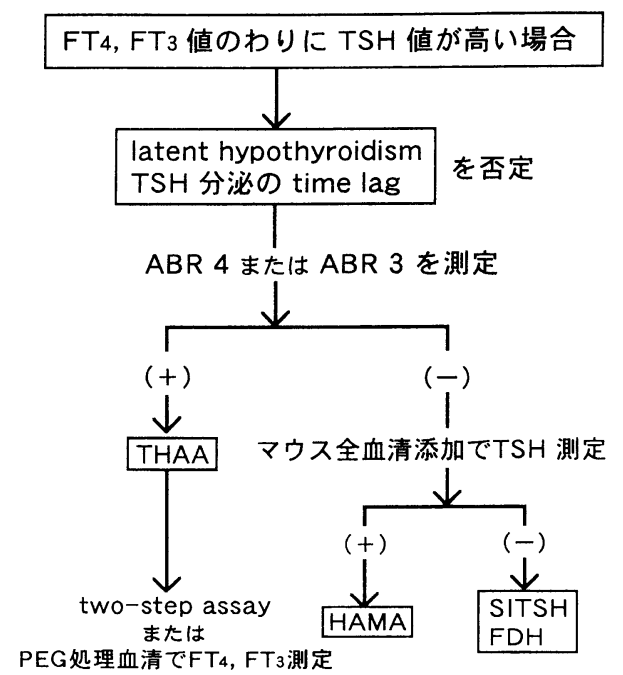

Fig. 5 遊離甲状腺ホルモン值と TSH 值間に解離を認める場 合の鑑別診断

THAA または異常アルブミンが存在した場合，これらの干渉を受けない実際の臨床像に見合った $\mathrm{FT}_{4}, \mathrm{FT}_{3}$ 值を得るためには，被検血清と tracerが接触しない測定法，すなわちtwo-step assay で測定するか，または $25 \%$ \% PEG（最終濃度12.5\%）で血清を処理し， $\gamma$ ーグロブリン199あるは異常アルブミン20)を沈澱させた 上清で測定するのがよい。今回の異常アルブミンの症例においても, 干渉を受けた $\mathrm{FT}_{3}$ 值が $19.3 \mathrm{pg} / \mathrm{ml}$ であ ったのに対して, two-step assay（IMx-FT ; ダイナボット社）のFT $3.1 \mathrm{pg} / \mathrm{ml}$ (N:3.2-5.5), PEG 処理血清 の $\mathrm{FT}_{3} 4.2 \mathrm{pg} / \mathrm{ml}$ とこの時のTSH $1.9 \mu \mathrm{U} / \mathrm{ml}$ に見合った值が得られた。

\section{結語}

遊離甲状腺ホルモン值とTSH值間に解離を認める症例に対するアプローチとして, THAA, HAMA, 異 常アルブミンの検出法について検討し，それをもとに臨床的検討を行った。

1） ABR4, ABR3を測定することにより求めたTHAAの頻度は, 甲状腺疾患全体で $2.3 \%$, 自己免疫性甲 状腺疾患で $4.7 \%$ \%゙あったが, 実際 $\mathrm{FT}_{4}$ またはFT 3 值に明らかな解離を生じさせるような THAAの頻度 はわずかであると考えられた。

2) TSH值に解離が認められた場合は，まずHAMAの干渉を疑い，マウス全血清を測定系に添加してTSH 值の変化を検討し, HAMAが否定されたならばSITSHの可能性を考える。ただし, HAMAの検討成績 からは, TSH值が抑制不十分の症例は全例HAMA陽性であった。また, HAMAの頻度は約 $1.8 \%$ と推 定された。 
3） $\mathrm{FT}_{3}$ 值と TSH值の間に解離が認められた27歳のバセドウ病患者血清について検討し， ${ }^{125} \mathrm{I}-\mathrm{T}_{3}$ analog に高 い結合性を示す異常アルブミンの存在が示唆された。

4) 遊離甲状腺ホルモン值とTSH值の間に解離が認められた場合は，THAA，HAMAまたは異常アルブミ ンのように測定系に影響を与える物質が存在している可能性を考慮することで合理的なアプローチがで きる。

\section{文献}

1) Premachandra BN, Walfish PG. Effects and clinical significance of exogenous thyroxine therapy in patients with circulating thyroid hormone autoantibodies. Am J Clin Pathol 1982; 78: 63-8

2 ) Sakata S, Nakamura S, Miura K. Autoantibodies against thyroid hormones or iodothyronine. Ann Intern Med 1985; 103: 579-89

3 ) Rajatanavin R, Fournier L, DeCosimo D, Abreau C, Braverman LE. Elevated serum free thyroxine by thyroxine analog radioimmunoassays in euthyroid patients with familial dysalbuminemic hyperthyroxinemia. Ann Intern Med 1982; 97: 865-6

4 ) Zweig MH, Csako G, Reynolds JC, Carrasquillo JA. Interference by iatrogenically induced anti-mouse IgG antibodies in a two-site immunometric assay for thyrotropin. Arch Pathol Lab Med 1991; 115: 164-8

5 ) Bock JL, Furgiuele J, Wenz B. False positive immunometric assays caused by anti-immunoglobulin antibodies: a case report. Clin Chim Acta 1985; 147: 241-6

6 ) Wilkins TA, Midgley JEM, Stevens RAJ, Caughey I, Barron N. Assay performance and tracer properties for two analog-based assays of free triiodothyronine. Clin Chem 1986; 32: 465-9

7 ) J $\phi$ rgensen PH, Skovsted L, Jensen KA. Abnormal gamma globulin binding of thyroid hormones. Acta Med Scand 1979; 205: 375 — 8

8) Pudek MR, McIntosh HW. Triiodothyronine-binding immunoglobulin in a euthyroid patient. Clin Biochem 1981; 14: 142-5

9 ) Konishi J, Iida Y, Kousaka T, Ikekubo K, Nakagawa T, Torizuka K. Effect of anti-thyroxin autoantibodies on radioimmunoassay of free thyroxin in serum. Clin Chem 1982; 28: 1389-91

10) Sakata S, Nakamura S, Komaki T, Kojima N, Takuno H, Kimata Y, Miura K. Prevalence of anti-thyroid hormone autoantibodies in healthy subjects and thyroid disorders. In: Lee M, Koh CS, Eastman CJ, Nagataki S, eds, Progress in Thyroidology. Seoul: Korean Medical Publishers 1989; 155-8

11) Boscato LM, Stuart MC. Incidence and specificity of interference in two-site immunoassays. Clin Chem 1986; $32: 1491-5$

12) Boscato LM, Stuart MC. Heterophilic antibodies: a problem for all immunoassays. Clin Chem 1988; 34: 27 - 33

13) Kahn BB, Weintraub BD, Csako G, Zweig MH. Factitious elevation of thyrotropin in a new ultrasensitive assay: implications for the use of monoclonal antibodies in "Sandwich" immunoassay. J Clin Endocrinol Metab 1988; 66: 526-33

14) Reynolds JC, Del Vecchio S, Sakahara H, Lora ME, Carrasquillo JA, Neumann RD, Larson SM. Anti-murine antibody response to mouse monoclonal antibodies: clinical findings and implications. Nucl Med Biol 1989; 16: 121 — 5

15) Zweig MH, Csako G, Spero M. Escape from blockade of interfering heterophile antibodies in a two-site immunoradiometric assay for thyrotropin. Clin Chem 1988; 34: 2589-91

16) Wickus GG, Caplan RH, Mathews EA, Pehling GB. Sudden appearance and subsequent disappearance of interference in immunometric assays of thyrotropin neutralizable with purified mouse IgG. Clin Chem 1991; 37: 595-6

17) Harvey RD, McHardy KC, Trainer PJ, Reid I. Interference in modified immunoradiometric assay for thyrotropin. Lancet 1988; 1 : 716

18) Gitlin D, Koch $\mathrm{K}$. On the mechanisms of maternofetal transfer of human albumin and $\gamma$ G globulin in the mouse. J Clin Invest 1968; 47: 1204-9

19) Sakata S, Komaki T, Nakamura S, Miura K. Measurement of free triiodothyronine in serum in the presence of autoantibodies to it. Clin Chem 1985; 31; 1252-3

20) Stockigt JR, Topliss DJ, Barlow JW, White EL, Hurley DM, Taft P. Familial euthyroid thyroxine excess: an appropriate response to abnormal thyroxine binding associated with albumin. J Clin Endocrinol Metab 1981; 53: 353-9

（受付日：'93.11.15）

（採択日：'94.1.17） 